\title{
The Analysis of University Students' Views on Mentally Challenged People's Participation to Sports Events
}

\author{
Nurgül Tezcan Kardaş ${ }^{1, *} \&$ Reşat Sadık ${ }^{1}$ \\ ${ }^{1}$ Sport Sciences Faculty of Sports Administration, Duzce University, Düzce, 81010, Düzce, Turkey \\ *Correspondence: Sport Sciences Faculty of Sports Administration, Duzce University, Düzce, 81010, Düzce, Turkey. \\ Tel: 90-506-307-81-84. E-mail: nurgultezcan@duzce.edu.tr
}

Received: September 14, 2018

Accepted: September 30, $2018 \quad$ Online Published: October 12, 2018

doi:10.5430/wje.v8n5p123

URL: https://doi.org/10.5430/wje.v8n5p123

\begin{abstract}
The aim of this study is to investigate university students' attitudes towards mentally challenged individuals' participation to sports activities. To collect the data, 'Attitude towards sports activities scale of individuals having mental disabilities' is used. Reliability of the scale, which has been developed by (İlhan et al., 2013) and consists of 28 items, is 0.96 . The options, respectively, follow as: I completely agree, I agree, I'm neutral, I disagree and I completely disagree. The study group consists of 420 students who study at Bülent Ecevit University in 2016-2017 Spring Term, and is selected randomly. The result shows that there is no statistically significant difference in the attitude ratings of mentally challenged individuals' participation to sports activities related to age, sex, types of education, or if there is any disabled individual living in participants' social environments. But, type of school is a significant variant. The ratings of attitude of the participants who selected the option, 'other' in their school type part in the tool are higher than of the one ones who selected the options, 'faculty' or 'vocational school'.
\end{abstract}

Keywords: disability, insufficiency, mentally handicap, special education, attitude

\section{Introduction}

Individual differences existing among people are accepted as a fact by the whole world. If an individual can carry on his/her daily activities on his/her own, he/she is accepted as "normal". When considered in that term, disability is defined as chronic disadvantages which distort the whole participation and harmony of an individual in the daily life (Yetim, 2014). From birth to death, human life consists of different phases. These phases start with birth; continue with childhood, adolescence, adulthood and end with old age. In each period, there are areas of language, mental, physical and social-emotional development that are affected by one another. Nevertheless, not every individual is able to implement these mentioned areas. In this case, inability arises. Inability is defined as a condition of a prevention and limitation of a normal activity or structure as a result of damages or deviations. "If an individual is, because of an inability, not able to play his/her role in the life as he/she needs to play based on age, gender, social and cultural differences, we can talk about the term disability" (MEB, 1997). According to another definition, "Disability is a lack of anatomical, physiological or psychological structure and function or as a result of an abnormal condition, a limit or incompleteness of activities which can be accomplished by a normal individual successfully" (Alçak, 2005).

Classifications of some features and education necessities to determine the inability and needs of an individual are made to plan his/her education better. The most common group in this classification is individuals with mental incompetence. Mental incompetence is the condition of being significantly subnormal in general mental activities which develops during the development period and, in addition, it is an inability in adaptive behavior (Diken, 2014). Nowadays, there are several of definitions of children with mental incompetence who are popular among children who need special education. These definitions show that not only the mental capacities of these children are considered, yet at the same time aspects such as socialization, language development, health etc. are also included. It should not be forgotten that mentally challenged children are also like normal children have needs such as loving, being loved, eating, drinking etc. The difference of these children from their normal peers is their involuntary underdevelopment in their physical, mental and social development (Özgür, 1993).

According to Zigler (1999) "Although individuals with mental incompetence have the same personality structure as 
the general population, the positive or negative experiences in their lives have brought them some features. We can list these features in sequence as; being in a low success expectation, being afraid of failing in their works, the need for social reinforcement, outward orientation and extreme dependence." Therefore, society contribution is of great importance in the development of these individuals. There are various factors in the development of the individuals and in providing social harmony. Undoubtedly, one of these factors is sport. Sport is an important factor in the physical, mental, emotional and social development of disabled people due to their disabilities.

It is known that sports is a tool that supports muscular and neural systems, mental reactions and physiological and metabolic development of the body and that physical activities has an effect of a kind of rehabilitation. Participating in sports activities provides with great benefits such as strengthening muscles, developing coordination, developing balance, developing attitude control, developing flexibility, developing respiratory and circulatory systems, and preventing spasticity (Yetim, 2014). In case opportunities are given, there will be development in the motor skills of mentally challenged individuals (Akın, 2015).

Some of the children with mental disabilities are physically very similar to the normal children and are talented as the normal children are. Mentally challenged children can be successful in many sports branches like other children with normal development. Generally, children with mental disabilities have a great physical strength. Often, in an uncontrolled process, children can use this strength negatively and convert it into aggressive tendencies. "However, in terms of the development of the child, this physical strength awaits to be channeled into a very positive aspect" (Kınali, 2003).

It is very important to determine and reveal the intelligence and learning features and physical and motor feature of the mentally challenged children in order to understand them and their needs better and to provide with more help in the light of these needs; and it is also very important for mentally challenged children to be in an adequate level of physical fitness in order to take part in activities, to be productive and to protect their health (Y1lmaz, et.al, 2006).

The fact that the socialization of an individual is a topic of early ages and, that physical education and sports activities are also a habit during childhood and adolescence make it necessary to approach socialization along with sport at the same time. According to Ergun, sport promotes the physical and spiritual structure and gives the child a social role by giving the feeling of discipline, trust, competition and friendship. For disabled individuals, universal language of this social role is sport. Sport, as an educational, activity reveals the ability to express common goals and the feeling of appreciation. "In addition to these, sport also improves abilities in understanding and responsibility and in providing order in cooperation" (Ergun, 2003).

We can see that individuals collect information about many things such as individuals that they encounter, events, objects and ideas while they are in the process of perceiving the environment in their lives. The individual who is under the influence of this information creates his/her own thoughts and values and directs his/her attitude over time. "Attitude is more or less learned emotive response to any stimulus"(Gürün, 1991). "In the societies, there are positive, neutral and negative effects of individuals affected by the inability on the attitude of individuals with normal development" (Payne, 2014). The perception of the disabled people about the society is important as much as the perception of normally developed people about disabled people. Especially the point of view that the disabled people should be directed to sport has a different quality in terms of social development. In this context, it is important to determine the attitudes of the groups at various stages of society towards the disabled people. Undoubtedly, one of the most important of these stages is university students. University students are socialized individuals who have characteristics like being able to make decisions, being future parents, being part of economic life, getting training in different occupational groups and developing a positive perspective of the usefulness in sport orientation for disabled people in employment. It is necessary to measure the sensitivities of these socialized young dynamic brains about individuals with special needs. There are many studies on university students' attitudes towards disabled individuals (Craig, 1991).

In the study carried out by Gürsel (2006) with the topic "The effect of (the subject) physical education and sports lessons for disabled students on the attitude of the students towards the disabled people" have shown that (the subject) physical education and sports lessons for disabled people have a positive effect on the attitudes of students of the department of physical education and sports towards disabled individuals. In the study carried out by Özer (2016) with the topic "Physical education and sports lesson applications for disabled people from the point of view of physical education teacher candidates" have displayed that in spite of the duration of lesson of physical education and sports for disabled people and in spite of the fact that the most physical education teacher candidates have contact with children with disability for the first time, within the scope of "change with contact" there are significant positive changes. 
The positive perspective of disabled people should be in all areas. Thusly, encouraging disabled people for doing sports and the necessity of doing sports should be known and acted on by all members of society. Especially, the attitudes of university students, who are an important part of the society, are very significant. "Attitude is the pre-tendency of the cognitive, emotional, and behavioral reaction that an individual organizes based on experience and knowledge of any object or event around or about himself" (Baysal, 1981). In other words, the attitude is "a situation of permanent readiness, determining the individual's positive or negative emotional reaction to an object or situation stigmatized by any value judgment of a psychological process"(Sherif \& Sherif, 1996). According Kağıtçıbaşı (2005) "(the) attitude is a tendency that is attributed to an individual and that regularly forms the thoughts, feelings and behaviors about a psychological object". In this sense, attitude means being ready for a certain behavior. Attitude is the tendency or orientation about a person, a group, a category and behavior (Tezcan, 1995). According to another definition, attitude is a phenomenon that is obtained by learning, which directs the behavior of an individual and causes bias in making decision process (Tavşancil,2002; Erkuş, 2003; Kan \& Akbaş, 2005; Canakay, 2006).

Experts say that the ages of individuals are important in the formation of attitudes. Especially, the ages between 12 and 30 are the critical period in the formation of attitudes. They divide this period into adolescence (between 12 and 21) and first adulthood (between 21 and 30). They say that attitudes shape up in the adolescent period and that in the early adulthood period, the attitudes are increasingly crystallized (takes the form) (Morgan, 2000). The aim of this study is to evaluate the attitudes of university students towards the sportive activities of mentally challenged individuals. At the same time, the study draw attention about the positive development process when mentally retarded individuals are directed to sport and serves to develop a point of view of disabled individuals.

\section{Materials and Methods}

This research, which is a descriptive research, analyzes the attitudes of university students towards sportive activities of mentally retarded individuals. In the research, survey method was used. "The survey method is usually used in educational research to learn the attitude, beliefs and opinions of a selected group on a particular topic" (McMillan \& Schumacher, 2006).

\subsection{The Study Group}

The study group consists of 420 students who are selected randomly with sampling method from Bulent Ecevit University, spring semester of 2016-2017 academic year. The students are from the Faculty of Engineering $(\mathrm{n}=70)$, the Faculty of Arts and Sciences $(n=60)$, Faculty of Economics and Administrative Sciences $(n=60)$, the Higher School of Physical Education and Sports $(\mathrm{n}=55)$, the Theology Faculty $(\mathrm{n}=55)$, the Health Sciences Faculty $(\mathrm{n}=$ $60)$ and the State Conservatory $(n=60)$.

Table 1. Frequency and Percentage Distribution for Variables

\begin{tabular}{ccccc}
\hline & & f & \% & Total \\
\hline \multirow{2}{*}{ Age } & $18-20$ & 113 & 26.9 & \\
& $21-23$ & 248 & 59.0 & 420 \\
Type of Education & $24-27$ & 59 & 14.0 & \\
& Daytime education & 283 & 67.4 & \multirow{2}{*}{ Gender } \\
& Evening education & 137 & 32.6 & \\
& Female & 212 & 50.5 & \multirow{2}{*}{420} \\
School Type & Male & 208 & 49.5 & \multirow{2}{*}{ Faculty } \\
& Junior School of higher education & 304 & 72.4 & \\
& Other & 57 & 13.6 & 420 \\
Class & 1 & 79 & 14.0 & \\
& 2 & 18.1 & \\
Do you have disabled & 3 & 131 & 31.2 & \multirow{2}{*}{420} \\
people in your family or & 4 & 31.7 & \\
relatives? & Yes & 80 & 19.0 & \\
\hline
\end{tabular}




\subsection{Data Collection Tool and Data Collection}

In the study, a two-part questionnaire was prepared to determine the attitudes of university students towards sportive activities of mentally challenged individuals. In the first part of the questionnaire, the personal information form developed by the researcher was used to learn the personal information of university students. In this form, questions were asked to determine the gender, age, education and school type. It is also asked if there are any disabled individuals in the class or their environments. In the second part of the questionnaire "Attitude Scale towards Sportive Activities of Individuals with Mental Disability (ZEBSEYTÖ)" was used. As a result of the analysis of validity and reliability study of the scale, which is developed by (Illhan et al., 2013) and which consists of 28 attitude items, carried out by the researcher on university students, the Cronbach's alpha reliability coefficient of the measurement instrument was 0.96 for the scale in general. The options are; 'I completely agree', 'I agree', 'I am neutral', 'I disagree' and 'I completely disagree'.

During the data collection, the necessary explanations about the scale were made to the students and voluntary students were asked to fill in the surveys according to the explanations made. The surveys were collected in the same way after the students get a certain period to fill it in. After the surveys were completed, the researcher examined all surveys, 20 out of 440 scales were determined as inaccurate or incomplete and were excluded from the study. The analyses were performed on 420 data.

\subsection{Data Analysis}

The analysis of the data was made according to the scores that the participants obtained from the 'Attitude Scale towards Sportive Activities of Individuals with Mental Disability' with the variables of gender, age, type of education, type of school, class, the presence or absence of disabled people in the social environment. According to the results obtained, it was seen that the data did not show normal distribution. For this reason, Mann Whitney U and Kruskal Wallis tests were used in the study.

\section{Results}

In this section, results and interpretations obtained from the analysis of the research are included.

Table 2. Descriptive Statistics Related to General Attitude

\begin{tabular}{cccccc}
\hline & N & Minimum & Maximum & Avarage & Ss \\
\hline Total & 420 & 1,82 & 4,79 & 3,68 &, 32442 \\
\hline
\end{tabular}

When the Table 2 is examined, it is seen that the general averages of participants attending to the survey towards the sportive activities of mentally challenged children is with the lowest Xave $=1,82$ and the highest Xave $=4,79$, with an average of 3.68 .

Table 3. Mann Whitney U Test Results

\begin{tabular}{|c|c|c|c|c|c|}
\hline & & f & Average & Wilcoxon W & $\mathbf{P}$ \\
\hline \multirow{3}{*}{ Gender } & Female & 212 & 215.00 & \multirow{3}{*}{42830.5} & \multirow{3}{*}{443} \\
\hline & Male & 208 & 205.92 & & \\
\hline & Total & 420 & & & \\
\hline \multirow{3}{*}{$\begin{array}{l}\text { Type of } \\
\text { education }\end{array}$} & daytime education & 283 & 209.65 & \multirow{3}{*}{59330.0} & \multirow{3}{*}{.836} \\
\hline & evening education & 137 & 212.26 & & \\
\hline & Total & 420 & & & \\
\hline \multirow{3}{*}{$\begin{array}{l}\text { Do you have } \\
\text { disabled } \\
\text { people in } \\
\text { your family } \\
\text { or relatives? }\end{array}$} & Yes & 96 & 225.89 & \multirow{3}{*}{66725.0} & \multirow{3}{*}{157} \\
\hline & No & 324 & 205.94 & & \\
\hline & Total & 420 & & & \\
\hline
\end{tabular}

When the Table 3 is considered, according to gender variable, the average of female participants is 215.00 , while male participants is $205.92, \mathrm{p}$ value is .443 , the average of participants in daytime education is 209.65 , while the average in evening education is 212.26 , $\mathrm{p}$ value is .836 and when the number of people with disabilities in your 
family or relatives variable question is considered, it is seen that the average of responders who chose "yes" is 225.89 the average of responders who chose "no" is, 205.94 and the o value is .157.

Table 4. Kruskal Wallis Test Results

\begin{tabular}{cccccc}
\hline & & N & Average & Df & P \\
\hline \multirow{4}{*}{ Age } & $18-20$ & 113 & 218.92 & & \\
& $21-23$ & 248 & 209.88 & 2 & .526 \\
& $24-27$ & 59 & 196.99 & & \\
School & Total & 420 & & & \\
Type & Faculty & 304 & 199.40 & & \\
& Junior School of higher education & 57 & 201.74 & 2 & $000 *$ \\
& Other & 59 & 276.14 & & \\
& Total & 420 & & & \\
Class & 1 & 76 & 210.66 & & \\
& 2 & 131 & 215.74 & 3 & .824 \\
& 3 & 133 & 211.80 & & \\
& 4 & 80 & 199.60 & & \\
\hline
\end{tabular}

$p<.05 *$

When the Table 4 is examined, it is seen that the average of participant in the age range of 18-20 years is 218.92 , of participant in the age range of 21-23 years is 209.88, the average of those between the ages of 24-27 is 196.99 , the value of $\mathrm{p}$ is .526; in terms of the variable of school type, the average of the participants of the faculty is 199.40 and the average of the participants of the School of higher education is 276.14 , p, in terms of the variable of the class level, the average of the students in the first year is 210.66 , the students in the second year is 215.74 , the students in the third year is 211.80 , and the average of the students in the fourth year is 199.60 and the p value is .824 .

\section{Discussion and Conclusion}

In the table 2 , it is seen that the general averages of the participants towards the sportive activities of mentally challenged children is with the lowest Xave $=1,82$ and the highest Xave $=4,79$, with an average of 3.68. In this context, it can be said that the general average is not much higher than the middle level. For disabled individuals, the universal language of the social role is sport. Sport, which is a training activity, reveals the power to express common goals and the sense of appreciation. In addition to these, "sport improves bearing understanding and responsibility and also providing order in cooperation" (Ergun, 2003). Many studies show that disabled people gain important character traits through sport. In a study of Auxter and Pyeer, (1985), it was found that participation in sports activities has a significant contribution to the psychological, social and motor development of mentally challenged individuals and due to this contribution sport has a remedial effect on improving the motor skills on disabled people. Atan et.al.,(2016) have seen an increase in the performance of children with mental disability in their study 'the effects of sports on some motoric traits of children with mild mental disability '. İlhan et.al, (2013) investigated the effects of regular physical education and sport activities on the life quality of mentally disabled children in their research and determined that there is a difference in the quality of life of the experimental group who regularly participate in physical education and sport activities in favor of the experimental group. It is expected that the university students are aware of this situation. Therefore, it will be appropriate to do necessary work in order to make them become more sensitive about the subject and it may be appropriate to provide information about the importance of doing sport for disabled people.

As it is seen in the Table 3, when the scores that the university students obtained from the "Attitude Scale towards Sportive Activities of Individuals with Mental Disability' is analyzed by comparing according to gender, age, type of education, type of school, class and the presence or absence of disabled people in social environment, it can be said that the scores that the university students obtained from the "Attitude Scale towards Sportive Activities of Individuals with Mental Disability' do not display any significant difference in terms of gender. It can be said that participants of daytime and evening education are on similar levels in terms of attitudes towards sports activity participation of mentally challenged individuals. When the question, if there are any mentally challenged individuals in your family or relatives or not is considered, no significant difference has been found. It could be expected that the 
participants who have disabled people in their family or in their relatives approach the subject matter more sensitively. Nevertheless, the results of the research show that such a difference is not statistically relevant.

In the Table 4, it can be said that the scores the university students obtained from the 'Attitude Scale towards Sportive Activities of Individuals with Mental Disability' show a significant difference in terms of type of school. The scores of participants who chose school-type "other" were significantly higher than for school-type "faculty" and "School of higher education" participants in terms of their scores for the attitude towards participation of mentally disabled individuals in sports. On the other hand, it can be explained that the conservatory students approach to the "sports activity participation of mentally challenged individuals more sensitively when compared to the university students with the school type "faculty" and"school of higher education". The scores that the university students obtained from the 'Attitude Scale towards Sportive Activities of Individuals with Mental Disability' are examined by comparing values in terms of class level and the results of the scores of the attitude towards sportive activities of individuals with mental disability of university students do not show any significant difference according to class level. It can be said that participants of the survey who are in different classes are at similar levels in terms of attitudes towards sportive activities of mentally challenged individuals.

As a result, when we look at the attitudes of the students participated in the study about the attitudes towards the sports activities of mentally challenged individuals, there are no significant difference between the gender variables and it is seen that the attitude of them are on a similar level. Within the scope of the study, it was seen that different types of education, age and class levels do not lead to a change in their attitudes towards sportive activities of mentally challenged individuals. The attitudes of the university students with the school type "other" towards the sportive activities of mentally challenged individuals are significantly higher than those with the school type "faculty" and "School of higher education". It can be said that the general attitude scores of the students are moderate and there are not many differences in student attitudes at various variables related to sports activities of disabled individuals. This leads to the conclusion that the students have similar affective attributes about taking part in sport for disabled people. Expanding the scope of the research and implementing it in larger study groups are important for sports' purposes. As a matter of fact, sports for everyone requires making sports opportunities available for everyone without discriminations such as social status, class, race or disability.

\section{Acknowledgments}

The authors thank Serpil Bülbül Kardaş who participated in this study.

\section{References}

Akın, S. (2015). Tthe effect of ball control practices in basketball on the hand skills of the educable mentally challenged children. International Sports Research Journal, 5(1), 1-13.

Alçak, M. (2005). Handbook of physical education teacher. Morpa Kültür Publication.

Atan, T., Eliöz, M., Çebi, M., Ünver, Ş., \& Atan, A. (2016). The Analysis of The Effect of Basketball Training on the Motor Skills of Educable Mentally Disabled Children. Sports and Performance Research Journal, 7(1), 29-35.

Auxter, D., \& Pyeer, J. (1985). Principles and methods of adated physical education and recration. Mosby College, Toronto.

Baysal, A. C. (1981). Attitudes in Social and Organizational Psychology. İstanbul University Publications Faculty of Management Publications, İstanbul.

Canakay, E. U. (2006). Developing an attitude towards music theory lesson scale. National Music Education Symposium, 26-28.

Craig, C. S. (1991). Labels and the attitudes of undergraduate physical education students toward disabled individuals. Physical Educator, 48(3), 142-146.

Diken, İ. (2014). The students with the need of special education and special education (10th ed.). Ankara: Pegem.

Ergun, N. (2003). Child with Physical Disability and Sports. Journal of Çoluk Çocuk, 5, 26:50.

Erkuş, A. (2003). Writings on Psychometrics. Turkish Psychologists Association Publishing: Ankara.

Gürsel, F. (2006). The effect of Physical education and sport lesson for the disabled students on the attitudes of students towards disabled people, The Journal of Education Faculty of Hacettepe University, 31, 67-73. 
Gürün, O.A. (1991). Dictionary of Psychology. İstanbul: İnk1lap Bookstor.

İlhan, E. K., Kırımoğlı, H., \& Filozoğlu Çokluk, G. (2013). The Effect of Special and Sports Program on the Quality of Life of The Children With Mental Retardation. Nigde University Journal of Physical Education And Sport Sciences, 7(1).

Kağıtçıbaşı, Ç. (2005). New person and people]. İstanbul: Evrim Publishing.

Kan, A., \& Akbaş, A. (2005). The study of developing an attitude towards chemistry lesson scale for high school students]. Mersin: Education Faculty Journal of Mersin University, 1(2), 227-237.

Kinal1, G. (2003). Physical education-art-music lesson education in mentally disabled. The children with different development] (Ed: A. Kulaksızoğlu), İstanbul: Epsilon Publishing, 244.

McMillan, H., J., \& Schumacher, S. (2006). Research in education evidence-based inquiry (6th ed.). Boston: Allyn and Bacon In.

MEB. (1997). Delegated Legislation on Special Education no. 573.

Morgan, C. T. (2000). Introduction to Psychology. (translated by Hüsnü Arıcı and Orhan Aydın). Ankara: Meteksan Inc.

Özer, D., \& Süngü, B. (2016). Application of Physical Education and Sport Lesson for Disabled People in the Point of View of Physical Education Teacher Candidates Hacettepe Journal of Sport Sciences, 27(1).

Özgür, İ. (1993). The effect of the education of parents with educable disabled children on parents and children, Unpublishe doctoral dissertation "Social Sciences Institute of Çukurova University" Adana.

Payne, C. (2014). The impact of language and disability type on attitudes toward persons with disabilities (Doctoral dissertation). Southern Illinois University At Carbondale.

Sherif, M., \& Sherif, C.W. (1996). Intorduction to Social Psychology. (Translated by: Atakay, M., \& Yılmaz, A.). İstanbul: Sosyal Publications.

Tavşanc1l, E. (2002). Measurement of attitudes and data analysis via spss. Ankara: Nobel Publishing and Distribution.

Tezcan, M. (1995). Introduction to Sociology (4th ed.). Ankara: Feryat Publishing.

Yetim, A.A. (2014).Sociological Approach to Disabled Sports. International Congres of Physical Education and Sports in Disabled, 3-9.

Yılmaz, M., Tank, S., İbiş, S., Yılmaz, B., \& Kestek, S. (2006). Analysis of Development as a Result of Macro-term Flexibility Training in Educable Mentally Disabled in 10-14 Age Group. The Journal of Physical Education and Sports, 8, 1-4.

Zigler, E., \& Bennet-Gates, D. (1999). Personality development in individuals with mental retardation. Cambridge University Pres. 